\title{
Green investment in construction sector in Russia: trends and analysis
}

\author{
Vasiliy Stoikov ${ }^{1}$ Violetta Gassiy $^{2 *}$,Veronika Panaseykina $^{2}$ and Elena Belyaeva ${ }^{2}$ \\ ${ }^{1}$ Moscow State University of Civil Engineering, Yaroslavskoe shosse, 26, Moscow, 129337, Russia \\ ${ }^{2}$ Kuban State University, 350040, Krasnodar, Russian Federation
}

\begin{abstract}
The paper is devoted to the green construction development in Russia. The main objects of the research are investments in the green construction market, social and economic impacts on its development. The authors consider the Russian experience of green investment, analyzing the trends and reasons for the insufficient level of construction based on green technologies in the country. The article examines in detail the legal basis of green investment, analyzes the data of Russian and foreign practice of green investment and the functioning of the green construction market. In conclusion, the authors make discuss the prospects for the development of green construction in Russia, as well as offer recommendations for further improving the mechanisms and approaches used.
\end{abstract}

\section{Introduction}

Global climate change has a significant impact on the life of society and economics. Currently, the main task of human beings is to ensure their safety in natural space, to reduce the risks of production and agriculture. Realizing the need for high-quality of living conditions, people construct buildings and housing objects using non-renewable resources and energy sources. This increases the pressure on the environment. Emissions from industrial enterprises producing construction materials also contribute to the formation of the gross volume of greenhouse gases in the atmosphere. In this regard, the problem of forming a green construction market and investing in green materials is urgent. The increase in the number of studies in the field of green construction, the impact of climate on the green production market proves the need for more in-depth research in this area.

Currently the green financing is becoming an integral component in achieving global and national sustainable development goals and in building the green economy. The active growth of green segment in the global financial market and responsible investments define new environmentally sustainable contours and prospects for the development of international financial system. The investment paradigm is changing in favor of so-called transformative investments, or investments of influence. It corresponds not only to a certain level of economic expectations, but also has the potential for social and environmental

\footnotetext{
* Corresponding author: vgassiy@mail.ru
} 
impact. According to experts' estimates, about $\$ 93$ trillion dollars will be invested for the implementation of green projects in the world by the year 2030. Therefore it requires the extension of appropriate financial tools [1].

At the same time, each country is looking for its own way of creating the mechanism for the financial support of innovations and investments of green modernization. In accordance with global goals and national development priorities its purpose concludes in the structural shifts implementations towards environmentally sustainable production and consumption.

The UN General Assembly resolution adopted The 2030 Agenda for Sustainable Development [2]. There are 17 Sustainable Development Goals and their achievement is estimated about $\$ 30$ trillion dollars. To accumulate them, a new ecosystem of global finance is being formed in the world - a system of responsible and green finance (so-called green financing ecosystem). It is based on the unity of three ESG factors - environment, social and governance. The system of green investment develops at the intersection of two spheres - financial market and environmentally friendly human activities including production and provision of services, projects implementation, manufacturing of goods, raising funds and investment strategies.

\section{Methods}

Environmentally sustainable production and consumption is the crucial point for the global climate change problem. The mass production and consumption lead to the gas emission increasing. The construction sphere does also harm to the environment. According to Hannah Ritchie and Max Roser from the World Resource Institute the share of commercial and residential buildings sector in total volume of global greenhouse gas emissions is $17.5 \%$, fig. 1 [3]. Therefore the green construction development could be considered as the tool for SDGs achievement.

Currently, green building is developing in several directions. In modern Russia, dilapidated buildings are a significant problem. Most of the buildings are characterized by high energy consumption. In fact, most of the country's territory operates on the basis of outdated communications. In such a situation, it is necessary to actively implement technological solutions that will increase energy efficiency and reduce its consumption. This applies to buildings that are being rebuilt or renovated. This problem is especially acute in relation to residential buildings, where utility costs are a significant social burden. In Europe, it has long been a practice to construct green buildings, including green roofs and green facades. Thus, the formation of the ecological framework of the city, environmentally sustainable architecture of the city takes place. To understand the level of energy efficiency and assess the potential for the introduction of new technologies, the rating system for assessing buildings according to their level of environmental sustainability is constantly being improved. However, such rating systems cannot be implemented without clear legal frameworks that determine the rules and norms for the development of green building in the country. Each country signed the Agenda 2030 realizes its own system of measures to the implementation of 17 goals and green construction. To achieve the goals, as well as to actively implement projects in the field of environmental sustainability, it is necessary to develop green investment - financial mechanisms for raising funds to promote the ideas of sustainable development. 


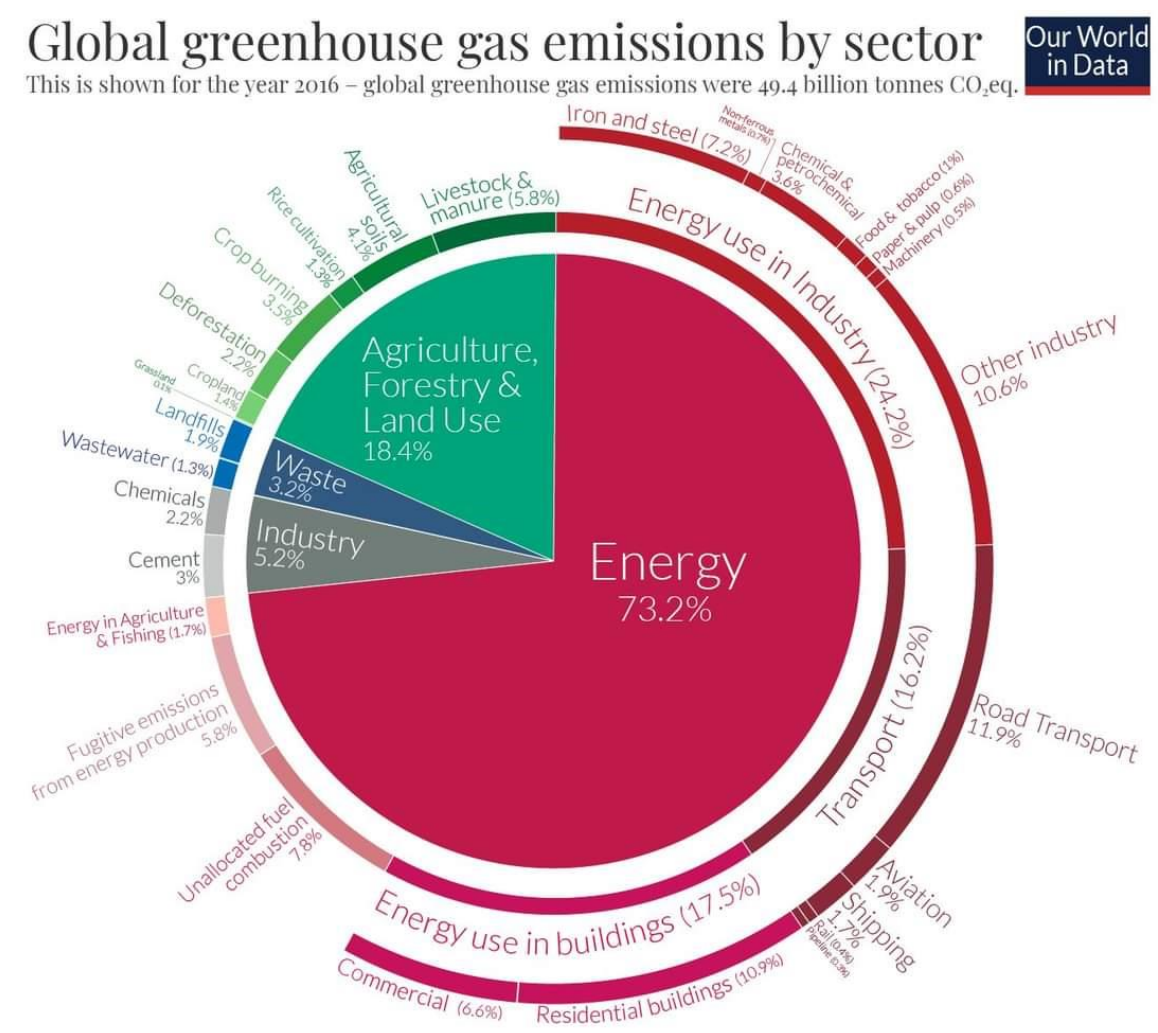

OurWorldinData.org - Research and data to make progress against the world's largest problems.

Fig. 1. Global greenhouse gas emissions by sector [3]

The Russian Federation has increased its activities in the field of green regulation since 2007. Since that time many legal acts on green regulation were adopted.

Table 1. Legal basis of green regulation in Russia

\begin{tabular}{|c|l|}
\hline Legal act & \multicolumn{1}{|c|}{ Basic characteristic } \\
\hline & - meeting domestic demand for energy resources; \\
& export development, infrastructure \\
Energy Strategy & modernization and its accessibility increasing; \\
(adopted in 2020) & achieving of technological independence; \\
& digital transformation and ensuring energy \\
& security. \\
\hline
\end{tabular}




\begin{tabular}{|c|c|}
\hline $\begin{array}{l}\text { The concept of long-term socio- } \\
\text { economic development of the Russian } \\
\text { Federation until } 2020 \\
\text { (adopted in 2008) }\end{array}$ & $\begin{array}{l}\text { - development of public-private partnership } \\
\text { aimed at reducing business and investment risks, } \\
\text { primarily in the areas of research and } \\
\text { development, dissemination of new technologies, } \\
\text { development of transport, energy and utilities } \\
\text { infrastructure; } \\
\text { - ensuring the progressive development of oil and } \\
\text { gas complex, the transition to new technologies } \\
\text { for the extraction and processing of fuel, the } \\
\text { increased demand for Russian machinery and } \\
\text { equipment; } \\
\text { - modernization of raw materials and processing } \\
\text { industries, increasing the depth of raw material } \\
\text { processing, reducing the energy intensity of } \\
\text { production and increasing its environmental } \\
\text { friendliness, expanding its presence in the world } \\
\text { markets of raw materials; } \\
\text { - acceleration of high- and medium-technical } \\
\text { production growth, the growth of knowledge- } \\
\text { intensive production, entry of enterprises into } \\
\text { external and domestic markets with new } \\
\text { competitive products having high value added. }\end{array}$ \\
\hline $\begin{array}{c}\text { Climate doctrine of the Russian } \\
\text { Federation } \\
\text { (adopted in 2009) }\end{array}$ & $\begin{array}{l}\text { The strategic goal of the climate policy is to } \\
\text { ensure the safe and sustainable development of } \\
\text { the Russian Federation, including the } \\
\text { institutional, economic, ecological and social } \\
\text { goals as well as demographic aspects of } \\
\text { development in a changing climate and the } \\
\text { emergence of relevant threats. } \\
\text { The main principles of climate policy are: } \\
\text { - the global nature of Russian Federation's } \\
\text { interests in relation to climate change and its } \\
\text { consequences; } \\
\text { - priority of national interests during } \\
\text { development and implementation of climate } \\
\text { policy; } \\
\text { - clarity and informational openness of policy in } \\
\text { the sphere of climate; } \\
\text { - recognition of need for action both within the } \\
\text { country and within the framework of full-fledged } \\
\text { international partnership of Russian Federation in } \\
\text { the international research programs and projects } \\
\text { related to climate change; } \\
\text { - comprehensive accounting of possible losses } \\
\text { and benefits associated with climate change; } \\
\text { - precaution in planning and implementation of } \\
\text { measures to ensure the protection of people, the } \\
\text { economy and the state from harmful effects of }\end{array}$ \\
\hline
\end{tabular}




\begin{tabular}{|c|c|}
\hline & climate change. \\
\hline $\begin{array}{l}\text { The Decree of the President of the } \\
\text { Russian Federation dated on } 4^{\text {th }} \text { of June } \\
2008 \text {, No. } 889 \text { "On some measures to } \\
\text { increase the energy and environmental } \\
\text { efficiency of the Russian economy" }\end{array}$ & $\begin{array}{l}\text { - taking measures for technical regulation aimed } \\
\text { at increasing the energetic and environmental } \\
\text { efficiency in such sectors of economy as electric } \\
\text { power, construction, housing maintenance, } \\
\text { utilities and transport; } \\
\text { - ensuring the transition to uniform principles for } \\
\text { the development of permissible environmental } \\
\text { impact standards; }\end{array}$ \\
\hline $\begin{array}{l}\text { The Decree of the President of the } \\
\text { Russian Federation 07.05.2018 N204 } \\
\text { "On National goals and strategic } \\
\text { objectives for the development of the } \\
\text { Russian Federation up to 2024" }\end{array}$ & $\begin{array}{l}\text { - establishment of an integrated system for the } \\
\text { management of municipal solid waste, including } \\
\text { the elimination of landfills and reclamation of the } \\
\text { territories where they are located, the creation of } \\
\text { conditions for the recycling of all production and } \\
\text { consumption of wastes prohibited for burial; } \\
\text { - implementation of comprehensive plans of } \\
\text { measures to reduce emissions of pollutants into } \\
\text { the air in large industrial centers; } \\
\text { - application by all facilities that have a } \\
\text { significant negative impact on the environment, } \\
\text { an environmental regulation system based on the } \\
\text { use of the best available technologies; } \\
\text { - improving the quality of drinking water } \\
\text { through the modernization of water supply } \\
\text { systems using advanced water treatment } \\
\text { technologies, including technologies developed } \\
\text { by organizations of the military-industrial sector; } \\
\text { - preservation of biological diversity, including } \\
\text { an increase of specially protected natural areas by } \\
5 \text { million hectares, the reintroduction of rare } \\
\text { species of animals, the creation of infrastructure } \\
\text { for ecological tourism in national parks, as well } \\
\text { as the preservation of forests, including on the } \\
\text { basis of their reproduction in all areas of felled } \\
\text { and dead forest plantations. }\end{array}$ \\
\hline $\begin{array}{l}\text { The Decree of the Russian } \\
\text { Government dated on } 8^{\text {th }} \text { of January } \\
\text { 2009, No. 1-r "On the main directions } \\
\text { of state policy in the field of energy } \\
\text { efficiency and in the electric power } \\
\text { industry basing on the use of } \\
\text { renewable energy sources for the } \\
\text { period up to 2020" }\end{array}$ & $\begin{array}{l}\text { Increasing the energy efficiency of the electric } \\
\text { power industry basing on the use of renewable } \\
\text { energy sources, which is necessary for reliable, } \\
\text { sustainable and long-term energy supply of } \\
\text { Russian Federation's economic development, and } \\
\text { it contributes to the involvement of innovative } \\
\text { science-intensive technologies and equipment in } \\
\text { the energy sector and to the development of local } \\
\text { high-tech generating production and auxiliary } \\
\text { equipment on this basis and is one of the } \\
\text { significant measures related to the fulfillment of } \\
\text { Russian Federation's international obligations to } \\
\text { limit emissions of greenhouse gases. }\end{array}$ \\
\hline
\end{tabular}


It should be noted that over the past year, the expert community has prepared a number of analytical materials that create the basis for developing the principles and methods of building the institutional system of green financing in Russia. The most significant of them include the following documents [4]:

- report "Establishment of the green bond market in Russia, taking into account international best practices. Results of the survey between the members of the Russian Council in connection to the Primary Capital Market", prepared by the self-regulatory organization "National Financial Association" (SRO NFA) in order to determine the current state of the green bond market and the prospects for its development;

- glossary "Green Economy: Definitions and Concepts", which is the translation of basic terms and concepts in the field of responsible financing, as well as a description of the main initiatives and companies that are involved in the development of this financial sector;

- World Bank Group Policy Brief "Green Financing in Russia: Creating the opportunities for green investment, identifying the problems, opportunities and potential ways to raise funds for ecologization of the Russian economy, institutional and market barriers to the development of green financing, as well as areas to build the capacity of the financial system in order to mobilize capital for green investments;

- "Recommendations in the sphere of Sustainable Development and Green Investments" prepared by the National Association of Concessionaires and long-term investors in infrastructure (NAKDI), as well as periodic reviews "Sustainable Development and Green Investments", presenting the examination of key events in the field of green financing, sustainable development and green investments in Russia and abroad;

- diagnostic paper "Green finance: The agenda for Russia" presented by the Working Group on issues relating to Responsible Financing (ESG-financing), including green financing, by the Expert Council on the long-term investment market at the Bank of Russia, which analyzes in detail the green trends in the world economy, the prerequisites for the creation of green finance market in Russia, the organizational and legal basis for its formation and development. The document also provides the assessment of market size, including an expert selection of potential green bonds issuers in Russia. The important component of this document is the well-designed map for the development of green finance market in Russia, including, in particular, the tasks to develop an ideology and consolidated position of regulators in relation to the green finance market at the national level, the range of activities to create a single national methodological center in the field of green finances, the creation and approval of principles, standards and taxonomy, the formation of verification system for green instruments and other measures.

Thus, in modern Russia, a comprehensive legal framework has been created for the implementation of a green economy and the concept of sustainable development. Therefore, we can conclude that there are real prospects for the implementation of green building as a mechanism for achieving sustainable development goals.

\section{Results}

In November 2015, a number of large Russian companies and banks - RUSAL, Sberbank, Rusnano, RusHydro and Ingosstrakh - came up with the idea of Russian partnership for climate preservation. Later, this idea was supported by several other organizations such as VTB Bank, Delovya Rossia, ALROSA, IK Russ-Invest, Ecopolis, the International Chamber of Commerce in Russia etc. It is possible to highlight the types of economic activities in which green investments are concentrated. Traditionally the main sectors of Russian economy are considered as "dirty" despite the fact that they are leaders of green 
investment. For example, extraction of mineral resources accounts for about $23 \%$ of green investments as well as manufacturing activities estimates about $44 \%$ of the total volume of green investments. The economic activities including petroleum and metallurgical production, electricity generation, gas and water distribution include over $26 \%$ of green investment. Analysis of data shows that in comparison with the total amount of fixed asset investment, the share of green investments is small. Although the basic types of economic activities are leaders in investments aimed at environmental protection and rational use of natural resources.

Basing on the Green Bond Principles of the Institute of Certified Management Accountants, Resursosberezhenie KhMAO LLC became the first issuer of green bonds in Russia. It finances and implements projects for the creation and operation of systems for the management of municipal solid waste (MSW) on the basis of concession agreements in the Khanty-Mansiysk Autonomous Okrug - Yugra (KhMAO) in Russia.

Under the terms of the concession agreement, Resursosberezhenie KhMAO LLC builds infrastructure and engineering facilities for waste management and equips the facility with all the necessary machinery and equipment. After that, all objects of the concession agreement become the property of the subject. In December 2018 this company placed 1.1 million bonds on the Moscow Stock Exchange with the total nominal value of 1.1 billion rubles, which were verified by the rating agency Rating-Agentur Expert RA GmbH [5].

In August 2019, on the Moscow Stock Exchange the first full-fledged platform for supporting ecological projects at the Russian financial market started to operate. Nowadays in Russia, five issues have placed seven emission of green bonds for a total amount of 7.55 billion rubles and $€ 500$ million euro. In comparison, at the international market in 2019 there were issued the green bonds worth $\$ 257.5$ billion dollars.

In 2019, Russian Railways JSC became the first company in the country to issue green bonds on the international market. At its last bond issue it saved on funding $0.3 \%$, which is a lot. The international market is now more capacious, since there are many investors, who in their memorandums set the restriction that they should invest a certain share of funds in green projects [6].

Theoretically the ecosystem of green investment consist of 4 elements, fig.2.

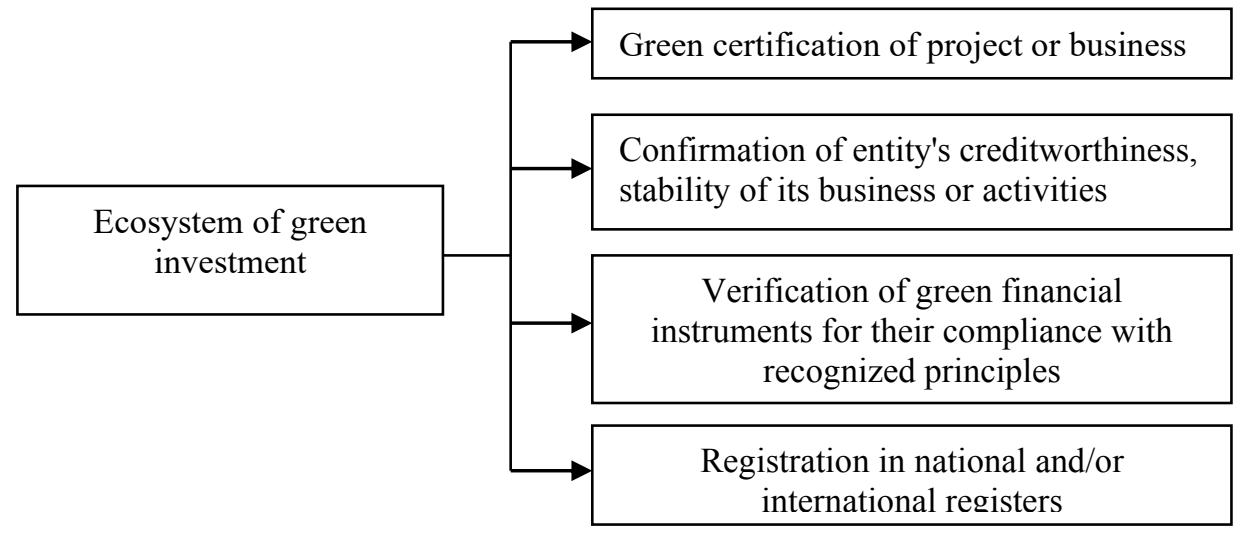

Fig. 2. Ecosystem of green investment

The green investment is one of the instruments for financing the transition of coastal territories to the principles of green economy and green growth, which contributes to the 
qualitative modernization of individual sectors and creates a multiplicative effect in the economy as a whole. Especially green investment is important for the construction sector. The world tendency is characterized by the increasing of investors' interest to the green construction. According to American Dodge Data \& Analytics, there are 3 main reasons of green construction growth [7]:

- Improving place of living and well-being;

- Encourage sustainable business practice;

- Increasing worker productivity.

However, at present the development of both individual projects in the sphere of green technologies development and green financing system in our country is at the initial stage. The active growth of green investments will contribute to the transfer to green technologies and the improvement of domestic enterprises' technical equipment.

According to experts, the developed countries annually spend about 2-3\% of Gross Domestic Product on environmental management. Many developing countries spend less than $1 \%$ of GDP on environmental management annually, believing that caring for the environment is not on the list of top priorities. In 2012, countries-participants of the Organization for Economic Cooperation and Development reported that the share of environmental expenditures in their national accounting systems has reached in average $1.1 \%$ of the total government expenditures. For example, Poland spends 1\%, Germany $1.2 \%$, Hungary $1.3 \%$, Switzerland $1.7 \%$, Greece $2.5 \%$, Slovenia $2.7 \%$ and Latvia $2.6 \%$ [8]. In Russia, the amount of governmental expenditures on environmental protection is comparable to the corresponding amount in developing countries. Over the period from 2003 to 2015, the share of environmental protection expenditures as a percentage of GPB decreased from $1.3 \%$ to $0.7 \%$ [9].

Development of green investment markets is important, not only in terms of mobilizing financial resources to meet Russia's sustainability goals, for green construction market and improving of well-being, but also as a way to manage financial risks related to the environment, climate change and financial sustainability.

\section{Conclusions}

It is possible to identify external and internal incentives for the development of green investments in Russia. Among the most important external incentives in the modern realities we offer to identify the following:

- Tax incentives for companies in the dirty sector for the introduction of green technologies and the implementation of environmentally friendly policy;

- The need for proactive action in the sphere of standards and rules establishment in the green financial markets;

- International obligations of the Russian Federation in relation to environmental objectives in accordance with the Paris Agreement on Climate Change;

- Strengthening the importance of environmental and low-carbon indicators in business ratings.

The main internal incentive for the development of green finance tools is the need to harmonize environmental and economic policy instruments in the context of ongoing process for environmental reform in the Russian economy.

The performed study made it possible to identify the factors stimulating and limiting the development of green investments in Russia: 
1. Factors of green investment stimulating: energy security; powerful multiplicative effect; ecological purity; environmental safety; reducing the risks of climate change; science intensity and competitiveness.

2. Factors of green investments limiting: high level of conservatism in economic development; substantial differences in the green economy development; the nature and scale of the green investments impact on economic growth; ambiguity of the investments' impact on the green economy development, on the growth of production and employment in various industries and the non-production sphere [7].

In such conditions, the optimal solution is to create our own system of green investment in Russia through the formation of national financial institutions and instruments - the green bank, green funds, green stock exchange, green rating agencies, as well as other mechanisms to promote aspects of green construction sector.

The paper is funded by RFBR, project № 19-010-00194 A.

\section{References}

1. V. Gassiy, V. Stoikov, Renewable energy and green market development in Russia, E3S Web of Conferences, 207, 02009 (2020) doi.org/10.1051/e3sconf/202020702009

2. The 2030 Agenda for Sustainable Development (2015) Retrieved from: https://sdgs.un.org/ru/goals [Online Resource]

3. H. Ritchie, M. Roser. $\mathrm{CO}_{2}$ and greenhouse gas emissions. Published online at OurWorldInData.org (2017) Retrieved from: 'https://ourworldindata.org/co2-and-othergreenhouse-gas-emissions' [Online Resource]

4. N.N. Yashalova, V.S.Vasiltsov, I.M. Potravny, Decarbonization of ferrous metallurgy: objectives and regulatory instruments, Chernye Metally, 2020(8), 70-75 (2020)

5. Green Cash for Siberian Trash, January 19, 2019. Retrieved from: 'https://www.globalethicalbanking.com/green-cash-siberian-trash/' [Online Resource]

6. T.-H. Farhad, Y. Naoyuki, Sustainable solutions for green financing and investment in renewable energy projects, Energies, 13, 788. doi.org/10.3390/en13040788 (2020).

7. World Green Building Trends 2018: Europe, Dodge Data \& Analytics, 14 (2018)

8. R.Wüstenhagen, E. Menichetti, Strategic choices for renewable energy investment: Conceptual framework and opportunities for further research, Energy Policy, 40, 1-10, https://doi.org/10.1016/j.enpol.2011.06.050 (2012)

9. V. Gassiy, V. Stoikov, Renewable energy and green construction in the Arctic, E3S Web of Conferences, 207, 02008, doi.org/10.1051/e3sconf/202020702008 (2020)

10. E. Atamas, M. Bitarova, E. Belyaeva, V. Panaseykina, Green financing for national sustainable development, 5th International Conference on Economics, Management, Law and Education (EMLE 2019), 150-156, doi.org/10.2991/AEBMR.K.191225.027 (2020) 